\title{
BONUSES FOR PROJECT TEAMS IN ENTERPRISE WITH METAL PARTS PRODUCTION
}

\author{
${ }^{1}$ Pavel KOLOŠ, ${ }^{2}$ Andrea SAMOLEJOVÁ \\ ${ }^{1}$ VSB - Technical University of Ostrava, Faculty of Materials Science and Technology, Ostrava, \\ Czech Republic, EU, pavel.kolos.st@vsb.cz \\ ${ }^{2}$ VSB - Technical University of Ostrava, Faculty of Materials Science and Technology, Ostrava, \\ Czech Republic, EU, andrea.samolejova@vsb.cz
}

https://doi.org/10.37904/metal.2020.3654

\begin{abstract}
The article presents the results of a study of project managers involved in improving teams at an international industrial enterprise. The enterprise mass produces and customises metal parts for the transportation industry. The authors of the article conducted and evaluated a survey of project team managers involved in improving and manufacturing products and related processes at an international industrial enterprise which produces casts for the aviation industry. The article offers recommendations for remunerating work teams.
\end{abstract}

Keywords: Project team, bonus, work productivity, metal parts production

\section{INTRODUCTION}

Industrial production managed through projects is now a commonplace reality in national and multinational industrial enterprises. Experts across international branches of companies often participate in project implementation. Each project has requirements for time, costs and quality. Achieving these requirements defines the extent of the project's success [1]. When assembling teams, it is necessary to think about their structure, because diversity, whether age or national, supports creativity and can also contribute to greater competitiveness inside and among teams [2].

Distinguishing between individual and team bonuses is necessary. The main task in motivating individuals is to tailor motivational measures to each employee and define clear rules for bonuses which correspond to work performance or the results of work. In the case of awarding team bonuses, the greater emphasis placed on cooperation and the collective responsibility of the team for achieved results is a suitable tool for motivating project teams [3]. Here, individual performance is not as relevant as the performance of all team members as a group. Motivating a project team plays a fundamental role in achieving project objectives, but not all managers particularly devote sufficient attention or budgets to this aspect [4]. Motivating employees in general may involve financial bonuses for work performed; however, this is not the only means. Industrial enterprises apply many approaches in defining total bonuses for work performance and are more frequently seeking nonfinancial motivational tools for individuals and entire project teams [5]. For example, the knowledge and comparability of achieved group results substantially improves team productivity and strengthens the synergistic effect of a group effort [6].

A combination of financial, non-financial, fixed and variable bonus components facilitates design strategy and the achievement of an organisation's goals. For this to work, properly defining the criteria for obtaining the bonus is necessary. Employees appreciate when employers seek different ways to remunerate their contributions. Financial and non-financial bonuses both raise work morale and increase employee loyalty, thus reducing the risk that employees may leave the enterprise [7]. 
A fixed wage in itself does not stimulate better performance without different bonuses that reflect the results in work performance. The timing of a bonus is therefore important. It has been shown that the later a bonus is granted after completing a certain project, the less employees appreciate the bonus and associate it with the given work results [8]. This is also linked to the need to communicate with employees about their performance, appraise their contribution and give them constructive feedback. It is essential to emphasise positive aspects in this feedback yet also highlight the potential room for improvement. From an employee's perspective, this again has a positive effect on their relationship with the employer [9].

In any project, it is important to motivate employees to achieve the project's objectives by the planned deadline, according to the budget and in the required quality. An important aspect in motivation is the environment. For this reason, it is crucial to prepare an environment for employees where they have all the necessary resources and references to concentrate on their work performance and be limited as little as possible by negative aspects in achieving the project's goals [1].

By combining the defined remuneration rules and selected bonus categories with the remuneration process and all people involved in the process, such as project team employees, project managers, direct supervisors and management, a self-contained remuneration system is created [9]. It is also necessary to continuously monitor current trends in order to maintain competitiveness in a dynamically developing industrial environment [10].

The aim of the article is to offer recommendations for remunerating work teams in enterprises with metal parts production. The recommendations are based on survey of project team managers involved in improving and manufacturing products and related processes at an international industrial enterprise which produces casts for the aviation industry.

\section{SURVEY DEFINITION}

\subsection{Subject of the survey}

The subject of the survey was to define the relationships in remunerating project team members. Personal interviews of project managers were conducted, and the development of their teams' production was analysed according to the corporate statistical data. The survey was conducted at a multinational foundry which produces casts with materials such as aluminium, magnesium and Inconel 718. Because of the need to preserve trade secrets, the company will not be named.

\subsection{Respondents}

Team project managers from six branches were interviewed. These people have managed projects which focused on:

- $\quad$ improving processes in production, logistics, quality, technology and maintenance,

- $\quad$ investments into new machinery, preparations and equipment,

- development and implementation of new manufacturing.

The project managers are directly subordinate to the directors of individual branches and do not have any permanent, direct subordinates within the organisational matrix. In each project, they use employees subordinate to the head of the department where the given employees are permanently assigned. The project teams generally use employees from production, purchasing and logistics, quality, technology, engineering (construction designers, analysts, calculators), facility maintenance and management, and sales.

Before each project, the percentage of time a given person will devote to working on the project is agreed. Certain employees may also work on several projects at once. Often, employees from several company branches are involved in a single project. Each project is recorded in the internal project database, which contains all the information about the project, including an evaluation. 
Under the company's wage policy, all employees receive a basic wage without any regular, variable component.

\subsection{Data Collection Method}

The online questionnaire survey was conducted from January to mid-March, 2020. Its aim was to highlight the strengths and weaknesses of the project team remuneration system in use at the aforementioned multinational industrial enterprise.

The questionnaire was created as an open MS Excel file to collect data and shared on the SharePoint online storage site. Of the total 52 managers given the questionnaire, 40 managers from six company branches responded. The questionnaire response rate therefore was $77 \%$. In the second stage, a group discussion with these 40 project managers was organised in the Microsoft Teams application to obtain additional information about the project team remuneration system. Participation in the group discussion was $100 \%$. Each question from the form and the group survey was subsequently evaluated orally and graphically. An analysis of the survey questions and responses, which highlighted the strengths and weaknesses of the team remuneration system, follows in the next section.

To determine how many projects were underway at the six branches and the ratio of projects with financial or non-financial gains, the company's internal project database was analysed.

\subsection{Survey Results}

The results of the survey showed that all of the project managers are thoroughly familiar with the system for remunerating the employees of their project teams, and all are also informed about potential changes or modifications to the system. The results also showed that $60 \%$ of managers use bonuses to remunerate project team members, $20 \%$ use non-financial bonuses such as leisure vouchers (Flexi Pass), and $20 \%$ use no tools to remunerate members, meaning employees only receive their basic wage regardless of their work performance.

In the online discussion, the managers agreed that the crucial criteria for remuneration are successful completion of the project by the required deadline, within the given budget, and in the required product quality. They use corporate software to manage project team remuneration and enter the proposed bonuses. The software also determines the value of the bonuses according to the cost savings or the profits from the proposed project output and also who is required to approve the given bonus range. A minimum bonus of CZK 500 is awarded for financially measurable profits and savings of up to CZK 10,000, approved by the manager and HR specialist. The maximum bonus is CZK 20,000 for profits or savings of over CZK 1 mil, approved by the four top managers of the enterprise.

In projects whose financial savings or gains cannot be financially measured, the criteria for awarding an extraordinary bonus is the employee's subjectively evaluated performance and the duration of the project. Employees receive a bonus of CZK 500 for a standard approach and unlimited project, and up to CZK 6,000 for a non-standard approach and a project that continues for more than 12 months. For foreign employees, the equivalents are stipulated in respective currencies. The project savings are calculated before signing the project contract with all the stakeholders. The approval steps in the software only serve monitoring purposes.

An interesting finding revealed that both types of remuneration for projects are generally applicable to all employees across all branches around the world. Naturally, always in the currency of the given country.

An alternative in the Czech Republic is awarding non-financial bonuses in the form of leisure vouchers (Flexi Pass) up to a maximum of 500 points. These are awarded directly by the project manager from the allocated annual budget.

Over half of the bonuses are proposed directly by the project manager (55\%), while $30 \%$ of the surveyed project managers request a bonus proposal from the direct superiors of team members, and $15 \%$ ask the customer or project sponsor, primarily for reasons concerning evaluation and authority. This explains why $20 \%$ 
of the surveyed project managers do not award bonuses. Another interesting finding revealed which phase of the project decides who proposes the bonus. Only $15 \%$ of those surveyed agree on a remuneration system before work on a project commences, $5 \%$ of project managers discuss remuneration in the course of project implementation, and $80 \%$ of managers discuss remuneration only after the project is complete and during the evaluation and handover of the results to the customer.

As mentioned above, for projects with financial gains, the rules for remuneration are clearly defined. For projects with non-financial gains, however, many factors play a role, which is why bonuses are often denied by the people who approve them. In most cases, bonuses are denied by project managers, while $10 \%$ of subjectively proposed bonuses are rejected by the financial director.

How information about an awarded bonus is disseminated is also a factor in motivation. Only around $30 \%$ of bonuses are announced by the project manager.

\subsection{Results of the Internal Project Database Analysis}

The success of a project can also be evaluated from the information stored in the database. Data from the years 2015 - 2019 were therefore exported from the internal database into the MS Excel environment and subsequently analysed for the purposes of this article.

Over four years, the number of projects increased by $40 \%$ (from 168 to 236). Given that the key indicator for remunerating project team employees is successful completion of the project according to three project imperatives (time, costs, quality), a substantial increase can be seen in project growth rate, from $52.5 \%$ in 2015 to $89.5 \%$ in 2019. In 2015, projects with a financial gain accounted for only $59 \%$ in 2015 , while in 2019 , they comprised $81 \%$ of the overall project portfolio. Hence, both the enterprise and employees benefited from the increased proportion of projects with a financial gain.

Because 260 projects were unsuccessfully completed in 2015 - 2019, the root cause of the failure was also analysed. Compared to the scheduled deadlines, $31 \%$ of projects were completed late. Higher project costs caused $17 \%$ of projects to fail, and $10 \%$ failed because of insufficient quality. A substantial proportion of projects also failed because of a combination of time and costs $(29 \%)$.

Low motivation in employees was not officially recorded even as a single percent. It may have contributed to both delays and costs in the projects if the employees were not sufficiently motivated to find creative solutions. This was verified in the analysis of extraordinary bonuses awarded to project team members, which had grown in direct proportion to the success of projects with financial gains since 2015.

\section{RECOMMENDATIONS}

The survey showed direct, positive links between the performance bonuses for project team members and success rate of completed projects and the rate of achieved savings which the bonuses depended on. The structure of bonuses in the surveyed industrial enterprise was thus logically defined. Nevertheless, the survey of managers revealed weaknesses in remuneration, which should be eliminated. The weaknesses are as follows:

- Bonuses are approved by the direct superior (not the project manager), and bonuses for work on projects are linked to the bonuses for team members' regular work duties. This is unadvisable, as most bonuses for work on projects must be approved by a direct superior who does not have an adequate overview of performance for the project team and may be influenced by the overview of performance in regular duties. These areas should remain separate; the project manager is a better suited in terms of knowledge of the required results and content. Each employee to give better performance within their activities in the project group then within their regular work duties. However, if this performance is not duly remunerated, the employee's motivation may decline, even if they perform as a part of a team. 
- $\quad$ The system for remunerating projects with financial gain does not take into account the time spent by individual project team members. This means the final bonus for the entire team may be unfairly allocated according only to a division based on the number of members. Although the performance of the entire team, not the individual, is important, the final bonus should include the factor of time spent on it so that team members are not affronted by only being able to participate in one project for a single bonus in a year, while others may manage several projects with multiple bonuses.

Subjective appraisal by the project manager and bonus approver in projects with non-financial gain is an important factor in motivating employees to dedicate themselves more thoroughly to projects with financial gain at the expense of those without. It would be better to implement multi-level evaluation, for example, by applying the 180-degree method, where both project managers and members of the team and customers decide on the bonus.

Other recommendations for remunerating project team members were derived from the online interviews with managers, as follows:

- Define remuneration as far as possible according to objective and measurable evaluation criteria.

- $\quad$ Ensure all participants involved in remuneration are well-informed of the process.

- $\quad$ Clarify the authority for proposing and approving bonuses; ideally, these should be people with the best overview of teams and individual performances within a project's activities.

- Define a system which is clear and comprehensible to all employees.

\section{CONCLUSION}

The article described the results of a study of the project team remuneration system at an industrial enterprise producing casts for aviation industry and offered recommendations for eliminating the weaknesses revealed in this system. The system's strengths include the existence of instruments to reward employees for work on projects, which indicated that employees felt motivated to achieve their required work performance. An important finding indicated that all the project managers interviewed for the study were familiar with the remuneration system. The remuneration system for projects with financial gain and rules for approval are clearly defined. A major advantage of the system is international applicability across all the company's branches.

Based on the increasing success rate of completed projects and proportion of projects with financial gain, a certain correlation can be observed, as the growth of both indicators is similar in 2015 and 2019. It can be concluded that the remuneration system for projects with financial gain is a major motivational element and has firmly defined rules compared to projects with non-financial gain.

Remuneration has a crucial role in motivation. Unfortunately, it is not always possible to be entirely objective, because one fundamental aspect is involved this system - the human factor. In creating the remuneration system, it is therefore important to define the rules to be as objective as possible. The rules should, as far as possible, be specific, measurable, acceptable, realistic, and clearly defined, especially in terms of time.

\section{ACKNOWLEDGEMENTS}

\section{The work was supported by the specific university research of the Ministry of Education, Youth and Sports of the Czech Republic in VSB - Technical University of Ostrava No. SP2020/61.}

\section{REFERENCES}

[1] RADUJKOVIC, M., SJEKAVICA, M. Project management success factors. In Creative Construction Conference. Primosten: Elsevier Ltd., 2017, pp. 607-615. 
[2] VELINOV, E. Diversity management practices in the US tech companies. In 17th International Scientific Conference on Hradec Economic Days. Hradec Kralove: University of Hradec Kralove, 2019, vol. 9, part II, pp. 494-500.

[3] MUSAWIR, A., SERRA, M.E.C., ZWIKAEL, O., ALI, I. Project governance, benefit management, and project success: Towards a framework for supporting organizational strategy implementation. International Journal of Project Management, 2017, vol. 35, no. 8, pp. 1658-1672.

[4] BEEL, J. Project Team Rewards Rewarding and Motivating your Project Team. Scotts Valley: CreateSace LLC, 2007.

[5] ARMStRONG, M., TAYLOR, S. Řízení lidských zdrojů: moderní pojetí a postupy. Praha: Grada Publishing, 2015.

[6] AMOATEMAA, S.A., KYYEREMEH, D.D. Making employee recofnition a tool for achieveing improved performance: Implication for Ghanian universities. Journal of Education and Practice, 2016, vol. 7, no. 34, pp. 46-52.

[7] FERGUSON, L.K., REIO, T. Human resource managerial system and firm performance. Journal of Management Development. 2010, vol. 29, no. 5, pp. 471-494.

[8] HAIDER, M., AAMIR, A., HAMID, A.A., HASHIM, M. A literature analysis on the importance of non-financial rewards for employees' job satisfaction. Abasyn Journal of Social Sciences, 2015, no. 8, pp. 341-354.

[9] IMRAN, A., AHMAD, S., NISAR, Q.A, AHMAD, U. Exploring relationship among rewards, recognition and employees' job satisfaction: A descriptive study on libraries in Pakistan. Middle-East Journal of Scientific Research, 2014, vol. 21, no. 9, pp. 1533-1540.

[10] PETERSON, M.T. Motivation: How to increase project team performance. Project Management Journal, 2007, vol. 38, no. 4, pp. 60-69. 